\title{
Stability-Indicating HPTLC Method for Simultaneous Estimation of Amoxicillin Trihydrate and Ambroxol Hydrochloride in Bulk and Pharmaceutical Dosage Form
}

\section{Sohan S Chitlange*, Sneha R Tawargeri and Ritesh P Bhole}

Padm Dr D Y Patil Institute Pharmaceutical Science Research, Pimpri, Pune-411018, Maharashtra, India

\begin{abstract}
A rapid, precise, selective and sensitive HPTLC method for simultaneous determination of Amoxicillin trihydrate (AMOX) and Ambroxol hydrochloride (AMBRO) in pharmaceutical dosage form was developed and validated in the present work. The chromatographic separation was performed on precoated silica gel $60 \mathrm{~F}_{254}$ plates with Ethyl acetate: methanol: toluene: water: glacial acetic acid (6.0: 3.0: 2.0: 1.0: $0.5 \mathrm{v} / \mathrm{v}$ ) as the mobile phase with UV detection at $237 \mathrm{~nm}$. Retention factor for AMOX and AMBRO were found to be $0.32 \pm 0.04$ and $0.70 \pm 0.05$ respectively. Linearity was observed in the concentration range of 2000-12000ng/band for AMOX and 500-2500 ng/b and for AMBRO and the coefficient of regression for both the drugs was 0.9986 and 0.995 respectively. The method was validated for precision, robustness, and recovery and the values obtained were within the ICH limits. The LOD and LOQ values for AMOX were 105 and $220 \mathrm{ng}$ per band respectively and for AMBRO 50 and $120 \mathrm{ng}$ per band respectively. Drugs were subjected to oxidation, acid hydrolysis, base hydrolysis and sun light to apply stress condition for degradation studies as per ICH guidelines. The degradation products were well resolved from the pure drug with significantly different $\mathrm{Rf}$ values. Since the method could effectively separate the drug from its degradation products, it could be used as a stability-indicating method for analysis of individual drugs and the combined dosage form.
\end{abstract}

Keywords: HPTLC; Ambroxol hydrochloride; Amoxicillin trihydrate

\section{Introduction}

Amoxicillin trihydrate (AMOX) is chemically a (2S, 5R,6R) [[(2R)2 - amino-2(4- hydoxyphenyl) acetyl ]amino]-3,3-dimethyl-7-oxo-4thia-1-azabicyclo [3.2.0] heptane-2-carboxyic acid, and it belongs to class of broad spectrum antibiotics. AMOX is official in IP, BP, Eur Pharmacopoeia and USP [1-4]. Literature survey reveals that AMOX has been determined by spectrophotometry [5-7], HPLC [8-11], HPLC with fluorimetric detection [12], HPLC with photo diode array detection [13], voltametry [14].

Ambroxol hydrochloride (AMBRO) [trans-4-(2-amino-3,5dibromobenzylamino) cyclohexanol Hydrochloride] [15] is semisynthetic derivative of vasicine obtained from Indian shrub Adhatoda vasica. It is a metabolic product of bromhexine. It is used as broncho secretolytic and expectorant drug. It stimulates the transportation of the viscous secretions in the respiratory organs and reduces the stand stillness of the secretions [16]. It is official in IP [1]. Few methods have been reported in the literature for the determination of AMBRO individually or in combination with other drugs [17-19].

Combination of AMOX and AMBRO is used for Respiratory system and as anti-allergic. The chemical structures of AMOX and AMBRO are shown in Figure 1.

Study has been reported on simultaneous determination of AMOX
Amoxicillin

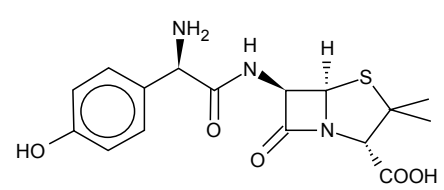

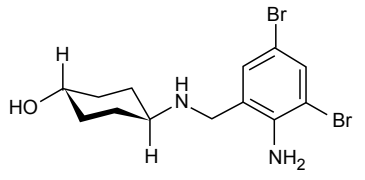

Ambroxol
Figure 1: Chemical Structures of Amoxicillin and Ambroxol. and AMBRO in human plasma by LC-MS/MS and HPLC method $[19,20]$. Literature survey reveals that there is no TLC densitometry method reported for the determination of these analytes in combination; therefore the aim of the present study was to develop rapid, accurate and reproducible TLC densitometry method for simultaneous estimation of AMOX and AMBRO from its formulation [21]. The attempts were made to establish the stability indicating, forced degradation methods [22-27]. Based on their results, we thought worthwhile to ascertain a new analytical method. To establish stability indicating nature of the TLC method, forced degradation of drug substances was performed under stress conditions (acid and base hydrolysis, oxidation). The proposed methods were validated as per the ICH guidelines $[28,29]$.

\section{Materials and Methods}

\section{Chemicals}

Gift samples of AMOX and AMBRO were provided by Elder Pharmaceuticals Pvt. Ltd., Mumbai. Solvents were obtained from Qualigens laboratory, Mumbai. All chemicals and reagents used were of AR grade. All solutions were prepared daily.

\section{Instrumentation and chromatographic conditions}

Thin layer chromatography was performed on $10 \mathrm{~cm} \times 10 \mathrm{~cm}$

*Corresponding author: Dr. SS Chitlange, Padm $\operatorname{Dr} D$ Y Patil Institute of Pharmaceutical Science Research, Pimpri, Pune-411018, India, Tel: 02027420261; Fax: 020-27420261; E-mail: sohan.chitlange@rediffmail.com

Received May 09, 2013; Accepted July 16, 2013; Published July 26, 2013

Citation: Chitlange SS, Tawargeri SR, Bhole RP (2013) Stability-Indicating HPTLC Method for Simultaneous Estimation of Amoxicillin Trihydrate and Ambroxol Hydrochloride in Bulk and Pharmaceutical Dosage Form. Pharm Anal Acta 4: 261. doi:10.4172/2153-2435.1000261

Copyright: (c) 2013 Chitlange SS, et al. This is an open-access article distributed under the terms of the Creative Commons Attribution License, which permits unrestricted use, distribution, and reproduction in any medium, provided the original author and source are credited. 
aluminum-backed TLC plates coated silica gel $60 \mathrm{~F}_{254}$ (E. Merck, Darmstadt, Germany; supplied by Merck India, Mumbai, India). The plates were prewashed by methanol and activated at $105-110^{\circ} \mathrm{C}$ for 15 min before use for chromatography. The samples in methanol were applied as bands $6 \mathrm{~mm}$ wide, $10 \mathrm{~mm}$ from the bottom and $20 \mathrm{~mm}$ from the sides of the plate, under a continuous flow of nitrogen, by means of a CAMAG Linomat-5 sample applicator fitted with a $100-\mu \mathrm{L}$ syringe. A constant application rate of $150 \mathrm{~nL} \mathrm{~s}^{-1}$ was used. The plate was then placed in pre-saturated twin-trough chamber (CAMAG; $10 \times 10$ $\left.\mathrm{cm}^{2}\right)$ containing the mobile phase, Ethyl acetate: methanol: toluene: water: glacial acetic acid (6.0: 3.0: 2.0: $1.0: 0.5 \mathrm{v} / \mathrm{v}$ ) and ascending development was performed to a distance of $80 \mathrm{~mm}$ from the point of application at ambient temperature. After development, plates were air dried, observed under UV chamber and densitometric scanning was performed at $237 \mathrm{~nm}$ with a CAMAG TLC scanner III operated in the reflectance-absorbance mode and controlled by WinCATS software version 4 . The slit dimensions were $5 \mathrm{~mm} \times 0.45 \mathrm{~mm}$ and the scanning speed was $20 \mathrm{~mm} \mathrm{~s}^{-1}$. Evaluation was by linear regression of peak area against the amount of sample per band.

\section{Preparation of standard solutions}

Standard stock solution of AMOX and AMBRO were prepared by dissolving quantity of $5.0 \mathrm{mg}$ of AMOX and $5.0 \mathrm{mg}$ of AMBRO separately in methanol in separate $10.0 \mathrm{ml}$ volumetric flask and final volume of both solutions were made up to mark with methanol to get a stock solution of $500 \mu \mathrm{g} / \mathrm{ml}$.

\section{Preparation of the sample solutions}

Twenty tablets were weighed and finely powdered; an accurately weighed powder equivalent to one tablet containing $3 \mathrm{mg}$ of AMBRO and $25 \mathrm{mg}$ of AMOX was taken and dissolved in the mobile phase and sonicated for $20 \mathrm{~min}$. and then volume was made up to the mark with mobile phase. The resulting solution was mixed and filtered through Whatmann filter paper No. 41. From the filtrate sample solution were applied to the TLC plate to give spot concentration $600 \mathrm{ng} / \mathrm{band}$ of AMBRO and the $5000 \mathrm{ng} / \mathrm{band}$ of AMOX. The plate was developed in the previously described chromatographic conditions. The peak areas of the spots were measured at $237 \mathrm{~nm}$ and concentrations in the samples were determined using multilevel calibration.

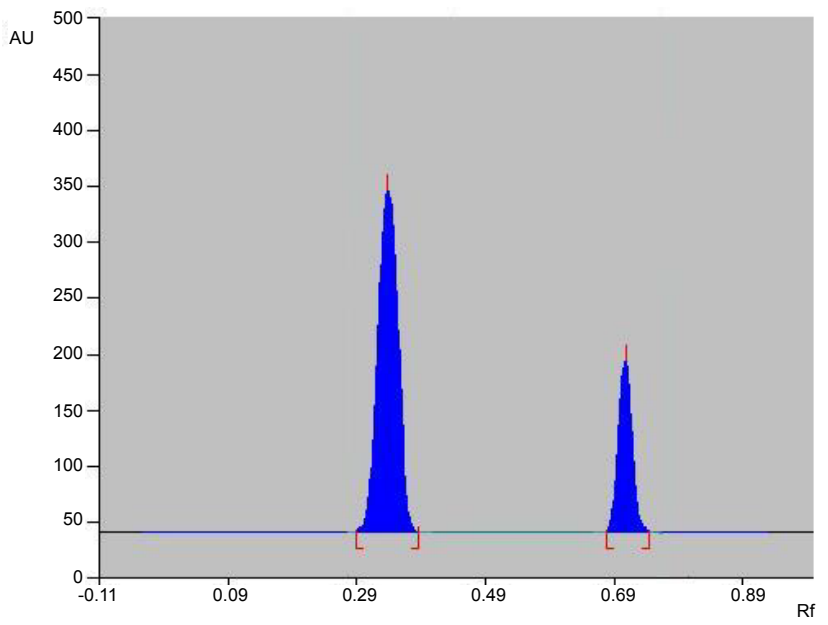

Figure 2: Densitogram of Amox (5000 ng/BAND, RF = 0.32) AND AMBRO (600 ng/BAND, RF=0.70).

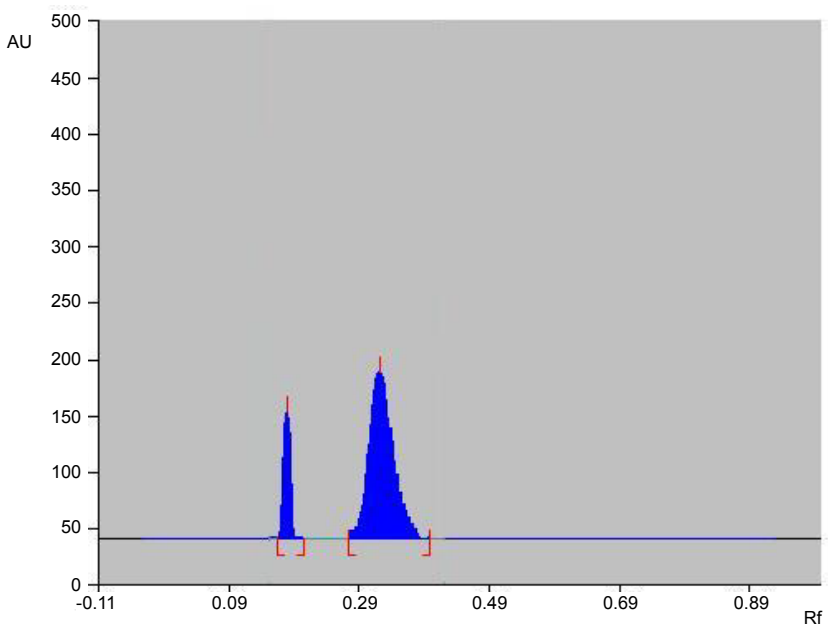

Figure 3: Chromatogram of Acid treated AMOX.

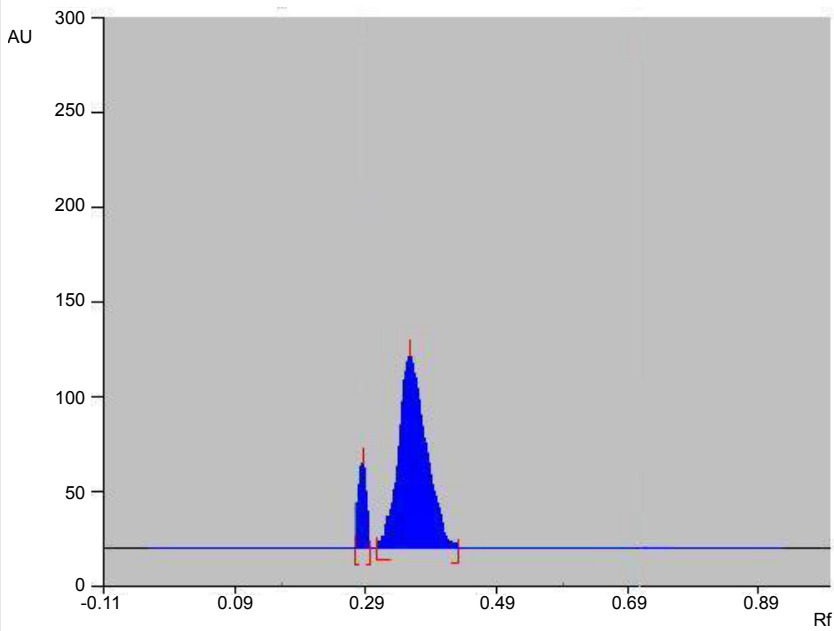

Figure 4: Chromatogram of Alkali treated AMOX.

\section{Method validation}

The method was validated in compliance with ICH guidelines [23].

\section{Procedure for forced degradation study}

For forced degradation studies, samples of AMOX and AMBRO were prepared separately under separate degraded conditions to maintain the \% degradation between $5-20 \%$ as per ICH guidelines $[22,23]$.

To study the acid degradation of AMOX, $1 \mathrm{ml}$ of $0.02 \mathrm{~N} \mathrm{HCl}$ was added to 5mg of Amox and made upto mark with methanol. It was then stirred continuously (with magnetic stirrer) for 15 minutes. For alkali and hydrogen peroxide degradation of AMOX, $1 \mathrm{ml}$ of $0.1 \mathrm{~N} \mathrm{NaOH}$ and $1 \mathrm{ml}$ of $3 \% \mathrm{v} / \mathrm{v}$ of $\mathrm{H}_{2} \mathrm{O}_{2}$ were added to separate volumetric flasks containing $5 \mathrm{mg}$ of AMOX and made up to mark with methanol. These solutions were allowed to stand for 6 hours at room temperature. For dry heat degradation of AMOX, the sample was exposed to sunlight for $2 \mathrm{hrs}$.

For the degradation studies of Ambroxol, $1 \mathrm{ml}$ each of $0.1 \mathrm{~N} \mathrm{HCl}$, 
Citation: Chitlange SS, Tawargeri SR, Bhole RP (2013) Stability-Indicating HPTLC Method for Simultaneous Estimation of Amoxicillin Trihydrate and Ambroxol Hydrochloride in Bulk and Pharmaceutical Dosage Form. Pharm Anal Acta 4: 261. doi:10.4172/2153-2435.1000261

$0.1 \mathrm{~N} \mathrm{NaOH}$ and $3 \% \mathrm{v} / \mathrm{v}$ hydrogen peroxide were added to $5 \mathrm{mg}$ of the AMBRO and made up to mark with methanol. These solutions were refluxed for two hours at $80^{\circ} \mathrm{C}$. For dry heat degradation of AMBRO; sample was exposed to sunlight for 12 hours.

\section{Results and Discussion}

\section{Optimization of procedures}

Different proportions of ethyl acetate, methanol, toluene and glacial acetic acid were tried while selecting the mobile phase. The addition of $1 \mathrm{ml}$ water to above combination improved the peak shape. Ultimately Ethyl acetate: methanol: toluene: water: glacial acetic acid (6.0: 3.0: 2.0: 1.0: $0.5 \mathrm{v} / \mathrm{v}$ ) was finalized as mobile phase. The spots developed were dense, compact and typical peak of AMOX and AMBRO obtained was shown in Figure 2. The peak was symmetrical in nature and no tailing was observed when plates were scanned at $237 \mathrm{~nm}$.

\section{Linearity}

Calibration curves were constructed in the concentration range of 2000-12000 ng/band for AMOX and 500-2500 ng/band for AMBRO. The beer's law is obeyed over this concentration range, and the coefficient of regression for both the drugs was 0.998 and 0.995 respectively.

\section{Analysis of formulation}

The spots at $R_{f} 0.32$ and 0.70 for $A M O X$ and $A M B R O$ were

\begin{tabular}{|c|c|c|c|c|c|}
\hline \multicolumn{2}{|c|}{ Label Claim (mg/tab) } & \multicolumn{2}{|c|}{ Amount Found $(\mathrm{mg} / \mathrm{tab})^{*}$} & \multicolumn{2}{c|}{$\%$ Amount Found \pm S.D } \\
\hline AMOX & AMBRO & AMOX & AMBRO & AMOX & AMBRO \\
\hline 25 & 3 & 25.12 & 2.99 & $\begin{array}{c}100.48 \pm \\
0.122\end{array}$ & $\begin{array}{c}99.66 \pm \\
0.512\end{array}$ \\
\hline
\end{tabular}

*Mean of six estimations

S.D $=$ Standard deviation

Table 1: Result of marketed formulation analysis

\begin{tabular}{|c|c|c|c|c|}
\hline Level of Recovery & Drug & $\%$ Recovery & $( \pm)$ Standard deviation & \%RSD $^{*}$ \\
\hline \multirow{2}{*}{80} & AMOX & 100.33 & 0.6923 & 0.6904 \\
& AMBRO & 99.66 & 0.2412 & 0.2398 \\
\hline \multirow{2}{*}{100} & AMOX & 101.31 & 0.7311 & 0.7289 \\
& AMBRO & 101.26 & 0.4554 & 0.4362 \\
\hline \multirow{2}{*}{120} & AMOX & 100.35 & 0.8129 & 0.8102 \\
& AMBRO & 98.82 & 0.3952 & 0.3911 \\
\hline
\end{tabular}

Table 2: Result of recovery studies.

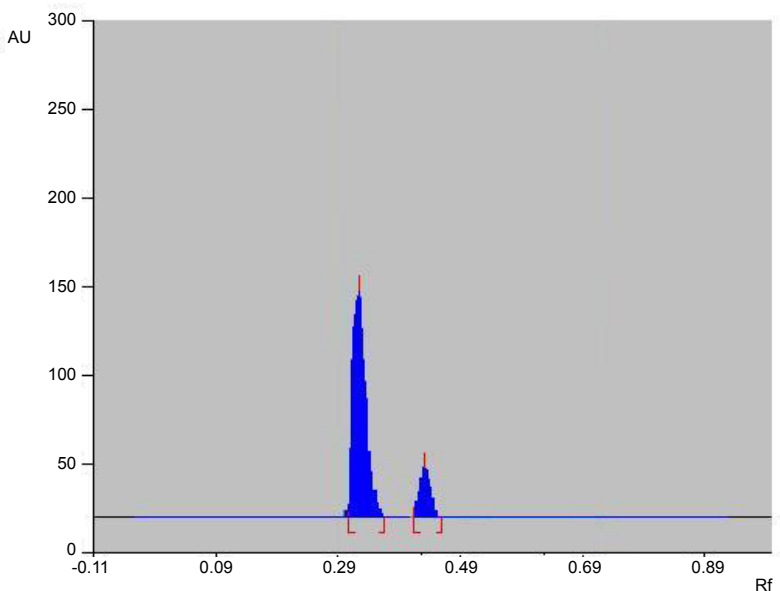

Figure 5: Chromatogram of Hydrogen peroxide treated AMOX.

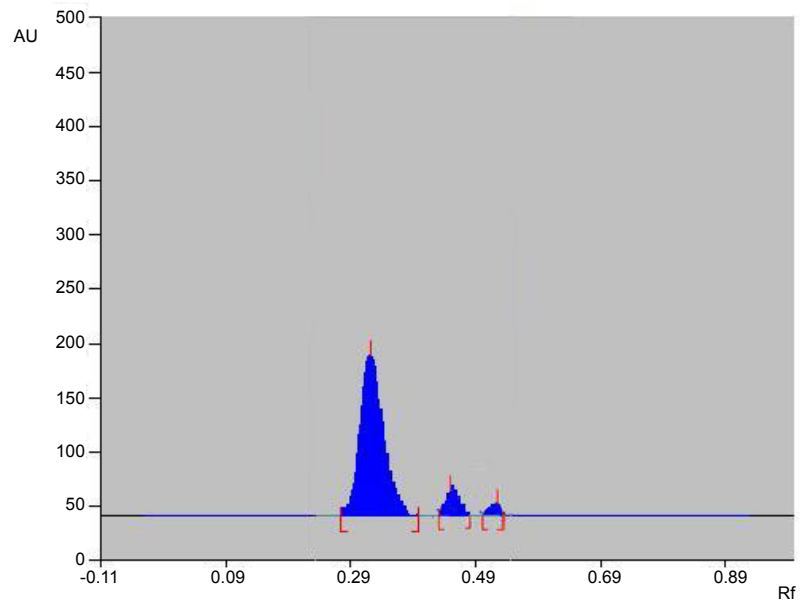

Figure 6: Chromatogram of AMOX exposed to sunlight.

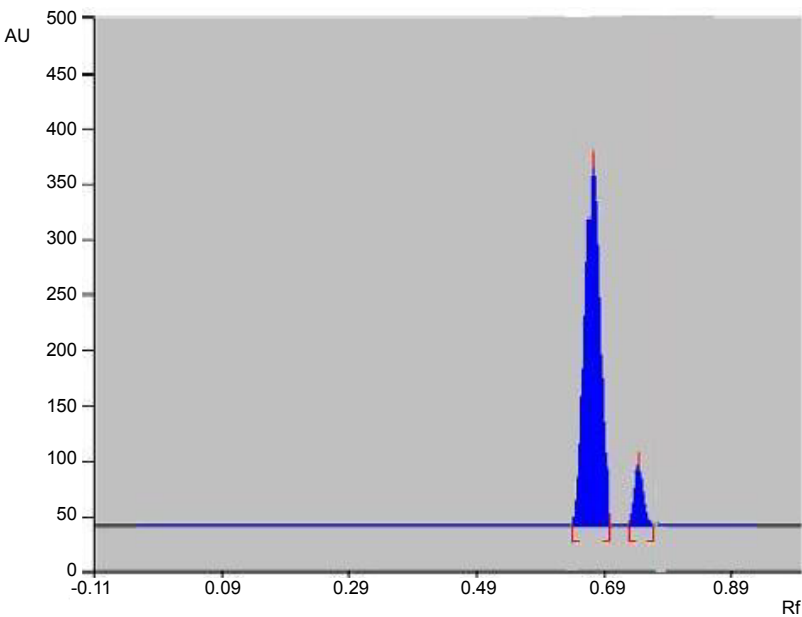

Figure 7: Chromatogram of Acid treated AMBRO.

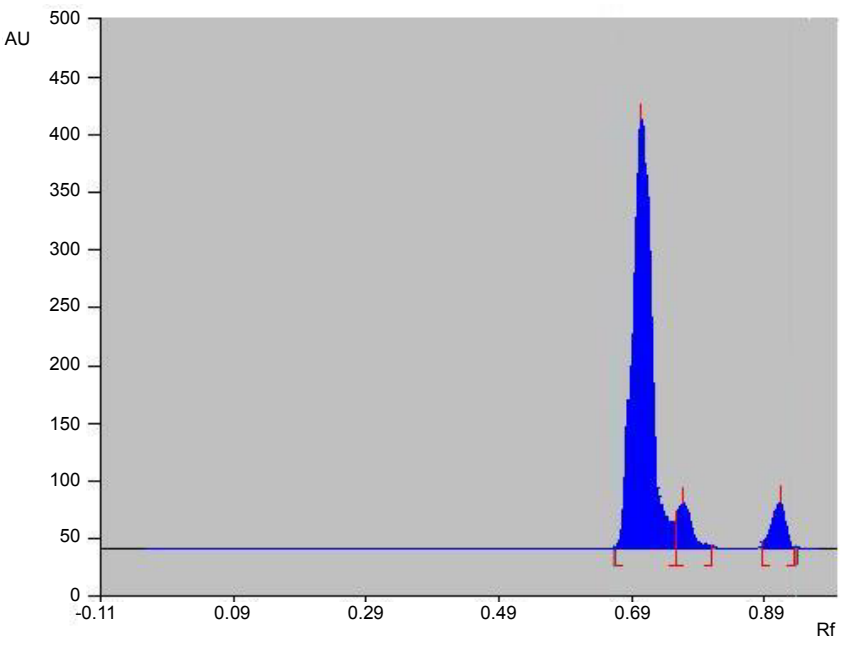

Figure 8: Chromatogram of Alkali treated AMBRO. 
Citation: Chitlange SS, Tawargeri SR, Bhole RP (2013) Stability-Indicating HPTLC Method for Simultaneous Estimation of Amoxicillin Trihydrate and Ambroxol Hydrochloride in Bulk and Pharmaceutical Dosage Form. Pharm Anal Acta 4: 261. doi:10.4172/2153-2435.1000261

Page 4 of 5

observed respectively in the densitogram of the drug samples extracted from tablets. There was no interference from the excipients commonly present in the tablets. The AMOX and AMBRO content was found to be close to $100 \%$ and the results are summarized in Table 1 . The low \%RSD value indicated the suitability of this method for routine analysis.

\section{Precision}

Precision was evaluated by carrying out six independent sample preparation of a single lot of formulation.

Percentage relative standard deviation (\%RSD) was found to be less than $2 \%$ for inter day and intraday variety of the both methods.

\section{Recovery studies}

To check the degree of accuracy of the method, recovery studies were performed in triplicate by the standard addition method at $80 \%$, $100 \%$ and $120 \%$. Known amounts of standard AMOX and AMBRO were added to the pre-analyzed samples and were subjected to the proposed method. Results of recovery studies for the both methods are shown in Table 2 .

\section{Robustness}

The robustness of the TLC densitometry method were determined by variations in methanol composition $( \pm 2 \%)$, chamber saturation period $( \pm 10 \%)$, development distance $( \pm 10 \%)$, the time from application to develop $(0,10,20,30 \mathrm{~min})$, time from development to scanning $(0,10,20,30 \mathrm{~min})$. One factor at a time was changed at a concentration level of $600 \mathrm{ng} / \mathrm{band}$ and $5000 \mathrm{ng} / \mathrm{band}$ for AMBRO and AMOX respectively, to study the effect on the $R_{f}$ and peak area of the drugs. The method was found to be unaffected by small changes with $\%$ RSD for all the parameters less than $2 \%$ indicating that the method is robust.

\section{Stability-indicating property [22]}

The stability study of AMOX and AMBRO under different stress conditions was carried out. AMOX underwent degradation faster than AMBRO owing to its susceptible beta lactum ring. AMBRO on the other hand was more stable and required harsher conditions to undergo degradation. The main peaks of both the pure drugs were well resolved from their degraded products. This shows the advantage of our mobile phase to effectively separate the peak of the pure drug from its degradation product. The amount of drug recovered after degradation studies and the Rf of degradation products are given in Table 3. The peaks obtained after degradation under various conditions have been shown in the figures 3-10.

\section{Conclusion}

The proposed TLC densitometry method was validated as per ICH guidelines. The standard deviation, \%RSD and standard error calculated for the method are low, indicating a high degree of precision of the method. The results of the recovery studies performed show a high degree of accuracy of the proposed method. The results of the stress studies indicated the specificity of the method. The method gives well-resolved peaks of AMOX and AMBRO even after exposure to different stress conditions when analyzed individually. The method

\begin{tabular}{|c|c|c|c|c|c|}
\hline Stress conditions & $\begin{array}{l}\text { AMOX } \\
\% \text { Assay of active } \\
\text { substance }\end{array}$ & $\begin{array}{l}\text { Rf values of } \\
\text { degraded }\end{array}$ & Stress conditions & $\begin{array}{l}\text { AMBRO } \\
\% \text { Assay of active } \\
\text { substance }\end{array}$ & $\begin{array}{l}\text { Rf values of degraded } \\
\text { products }\end{array}$ \\
\hline $\begin{array}{l}\text { Acid hydrolysis }(0.02 \mathrm{~N} \mathrm{HCl} 15 \\
\text { mnts stirring) }\end{array}$ & 86.31 & 0.17 & $\begin{array}{l}\text { Acid hydrolysis } \\
(0.1 \mathrm{~N} \mathrm{HCl}, \\
\left.2 \text { hrs reflux at } 80^{\circ} \mathrm{C}\right)\end{array}$ & 93.52 & 0.74 \\
\hline $\begin{array}{l}\text { Base hydrolysis } \\
(0.1 \mathrm{~N} \mathrm{NaOH} 6 \mathrm{hrs} \text { at RT) }\end{array}$ & 91.01 & 0.28 & $\begin{array}{l}\text { Base hydrolysis } \\
(0.1 \mathrm{~N} \mathrm{NaOH}, 2 \text { hrs reflux at } \\
\left.80^{\circ} \mathrm{C}\right)\end{array}$ & 89.33 & $0.72,0.83$ \\
\hline $\begin{array}{l}\text { Oxidation } \\
\left(3 \% \mathrm{H}_{2} \mathrm{O}_{2}, 6 \text { hrs at RT) }\right.\end{array}$ & 80.25 & 0.42 & $\begin{array}{l}\text { Oxidation } \\
\left(3 \% \mathrm{H}_{2} \mathrm{O}_{2}, 2 \text { hrs reflux at } 80^{\circ} \mathrm{C}\right)\end{array}$ & 83.21 & $0.77,0.81$ \\
\hline Exposed to Sunlight(2 hrs) & 84.21 & $0.46,0.52$ & $\begin{array}{l}\text { Exposed to } \\
\text { Sunlight(12 hrs) }\end{array}$ & 81.46 & $0.79,0.81$ \\
\hline
\end{tabular}

Table 3: Results of forced degradation studies.

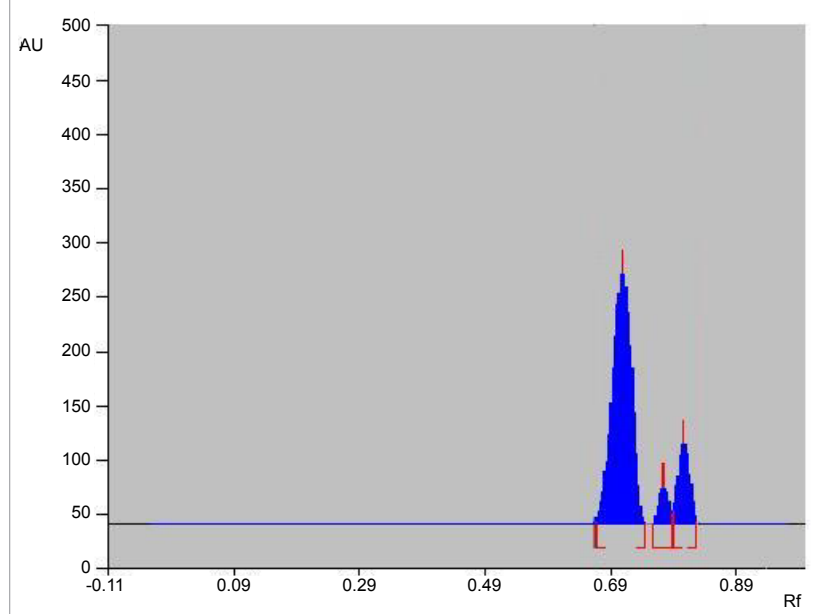

Figure 9: Chromatogram of Hydrogen peroxide treated AMBRO.

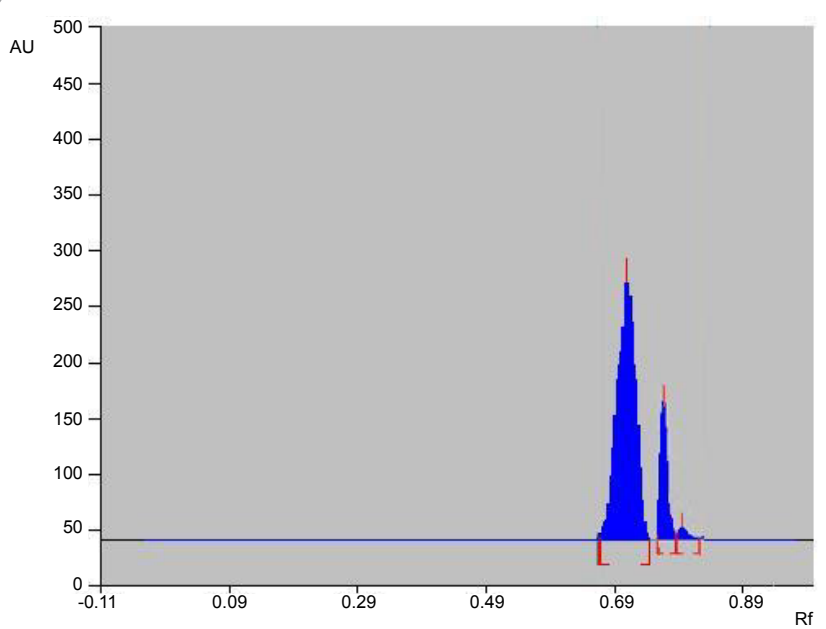

Figure 10: Chromatogram of AMBRO exposed to sunlight. 
Citation: Chitlange SS, Tawargeri SR, Bhole RP (2013) Stability-Indicating HPTLC Method for Simultaneous Estimation of Amoxicillin Trihydrate and Ambroxol Hydrochloride in Bulk and Pharmaceutical Dosage Form. Pharm Anal Acta 4: 261. doi:10.4172/2153-2435.1000261

Page 5 of 5

can be used to determine the purity of the drugs available from various sources by detecting the related impurities.

Statistical tests indicate that the proposed HPTLC and HPLC methods reduce the duration of analysis and appear to be equally suitable for routine determination of AMOX and AMBRO when compared with the reported methods. As the method is stability indicating one it may be extended to study the degradation kinetics of AMOX and AMBRO in combination. Hence, it can be concluded that the developed TLC-densitometry method is accurate, precise, and selective and can be employed successfully in the estimation of AMOX and AMBRO in bulk and in pharmaceutical formulation.

\section{Acknowledgement}

The authors gratefully acknowledge Dr. P.D.Patil, Chairman, Dr. D.Y.Patil Vidya Pratishthan Society for providing excellent infrastructural facility and University of Pune, Pune for providing financial assistance for the said work. Thanks also go to Elder Pharmaceutical Pvt. Ltd. Mumbai for providing pure drug gift samples.

\section{References}

1. Indian Pharmacopoeia (2007) 2: 701-722

2. British Pharmacopoeia (2007) 1: 144-147.

3. European Department of Quality medicines In: European Pharmacopoeia (2005) (5thedn). strasbourg: Supplement 5.1: 2925-2926.

4. United States Pharmacopoeia 30 (2007) National Formulary 25.Rockville MD: USP Convention Inc:1402.

5. Rahman S, Ahuja A, Ali J, Khar K (2004) Simultaneous spectrophotometric determination of amoxycillin trihydrate and metronidazole in dental films. Indian J Pharm Sci 66: 135-136.

6. Bobrowska GE (2001) Determination of amoxicillin and clavulanic acid in some pharmaceutical preparations by derivative spectrophotometry. Mikrochim Acta136: 31-34.

7. Daharwal SJ, Saraf S (2007) Spectrophotometric Determination for the Simultaneous Estimation of Amoxicillin and Tinidazole in the Tablet Dosage Form. Indian J Pharm Sci 41: 35-41.

8. Mascher JH, Kikuta C (1998) Determination of Amoxicillin in Human Serum and Plasma by High Performance Liquid Chromatography and Online Post Column Derivatisation. J Chromagr A 812: 221-226.

9. Abreu LR, Ortiz RA (2003) HPLC determination of amoxycillin comparative bioavailability in healthy volunteers after a single dose administration. J Pharm Sci 6: 223-230

10. Yuan Z, Russlie HQ, Canafax DM (1997) High-performance liquid chromatographic analysis of amoxicillin in human and chinchilla plasma, middle ear fluid and whole blood. J Chromatogr B Biomed Sci Appl 692: 361-366.

11. Zarapkar SS, Kolte SS, Bhandari NP (1998) High performance liquid chromatographic determination of amoxicillin trihydrate and probenicid simultaneously from pharmaceutical preparation. Indian Drugs 35:107-109.

12. Wibawa JI, Fowkes D, Shaw PN, Barrett DA (2002) Measurement of amoxicillin in plasma and gastric samples using high-performance liquid chromatography with fluorimetric detection. J Chromatogr B Analyt Technol Biomed Life Sci 774: 141-148.

13. Menelaou A, Somogyi AA, Barclay ML, Bochner F (1999) Simultaneous quantification of amoxycillin and metronidazole in plasma using highperformance liquid chromatography with photodiode array detection. J Chromatogr B Biomed Sci Appl 731: 261-266.

14. Qureshi SZ, Qayoom T, Helalet MI (1999) Simultaneous spectrophotometric and volumetric determinations of amoxycillin, ampicillin and cloxacillin in drug formulations: reaction mechanism in the base catalysed hydrolysis followed by oxidation with iodate in dilute acid solution. J Pharm Biomed Anal 21: 473-482.

15. Reynolds JE, Martindale (1996) The Extra Pharmacopoeia. (31stedn). London: Published By Direction of the Council of The Royal Pharmaceutical Society of Great Britain and Prepared in The Society's Publication Department: 1062.

16. Budavari S (1996) The Merck Index: An Encyclopedia of Chemicals, Drugs and Biologicals (12thedn). New Jersey: Published By Merck Research Laboratories Division of Merck and Co., Inc. Whitehouse Station: 67.

17. Pai PNS, Rao GK, Lalitha N, Pasha K (2006) Spectrophotometric determination of ambroxol hydrochloride. Ind J Pharm Sci 67: 741-742.

18. Bazylak G, Nagels LJ (2003) Simultaneous high-throughput determination of clenbuterol, ambroxol and bromhexine in pharmaceutical formulations by HPLC with potentiometric detection. J Pharm Biomed Anal 32: 887-903.

19. Wen A, Hang T, Chen S, Wang Z, Ding L, et al. (2008) Simultaneous determination of amoxicillin and ambroxol in human plasma by LC-MS/MS: validation and application to pharmacokinetic study. J Pharm Biomed Anal 48: 829-834.

20. Zarapkar SS, Rane SH (2000) Reverse phase high performance liquid chromatographic determination of amoxicillin and ambroxol hydrochloride in tablets. Indian drugs 37: 246-250.

21. Sohan S, Chitlange Kumar N, Sagar B, Wankhede (2009) Stability-indicating HPTLC method for

22. estimation of dexibuprofen in pharmaceutical dosage form. Journal of Pharmacy Research 2: 1542-1546.

23. Chitlange SS, Tawargeri SR, Chaturvedi KK (2011) Simultaneous Determination of Amoxicillin Trihydrate and Ambroxol Hydrochloride in Solid Dosage Form By Spectrophotometric and Stability

24. Indicating RP-HPLC Method. Asian Journal of Research in Chemistry 4: 1025 1030

25. Umadevi B, Vetrichelvan T (2011) Development and validation of UV spectrophotometric determination of doxofylline and ambroxol hydrochloride in bulk and combined tablet formulation. International Journal of Current Pharmaceutical Research 3: 89-92.

26. Dhaneshwar SR, Dhoka MV, Chopade SS, Bhusari et al (2011) Validated HPTLC Method for Simultaneous Estimation of Amoxycillin trihydrate and Ambroxol hydrochloride in Pharmaceutical DosageForm. Asian J Pharm Biol Res 1: 129-135.

27. Dong X, Ding L, Cao X, Jiang L, Zhong S (2013) A sensitive LC-MS/MS method for the simultaneous determination of amoxicillin and ambroxol in human plasma with segmental monitoring. Biomed Chromatogr 27: 520-526.

28. Deshpande MM, Kasture VS, Gosavi SA (2010) Application of HPLC and HPTLC for the simultaneous determination of cefixime trihydrate and ambroxo hydrochloride in pharmaceutical dosage form. Eurasian Journal of Analytical Chemistry 5: 227-238.

29. Mehta FA, Patelia EM, Bhoya PN (2013) Simultaneous Estimation of Ambroxol Hydrochloride and Doxofylline in Pharmaceutical Formulation by HPTLC Desitometric Method. Journal of Chromatography \& Separation Techniques 4 : $1-5$

30. International Conference on Harmonization (ICH) (2003) Harmonised Tripartite Guideline on, Topic Q1A, Notes for Guidance on stability testing: Stability testing of new drug substances and new drug products. Pub by The European Agency for the Evaluation of Medicinal Products, Human medicine evaluation Unit.

31. International Conference on Harmonization (ICH) (1996) Harmonized Tripartite Guideline on, Topic Q2B, Notes for Guidelines for Validation of Analytical Procedures:Methodology: Pub by The European Agency for the Evaluation of Medicinal Products, Human medicine evaluation Unit. 